\title{
Integrated Efficiency Test for Pyrochemical Fuel Cycles
}

\section{Global 2007}

S. X. Li

D. Vaden

B. R. Westphal

G. L. Fredrickson

R. W. Benedict

T. A. Johnson

\section{September 2007}

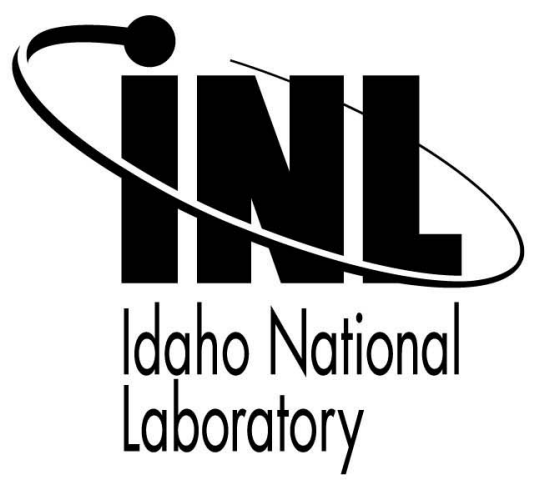

This is a preprint of a paper intended for publication in a journal or proceedings. Since changes may be made before publication, this preprint should not be cited or reproduced without permission of the author. This document was prepared as an account of work sponsored by an agency of the United States Government. Neither the United States Government nor any agency thereof, or any of their employees, makes any warranty, expressed or implied, or assumes any legal liability or responsibility for any third party's use, or the results of such use, of any information, apparatus, product or process disclosed in this report, or represents that its use by such third party would not infringe privately owned rights. The views expressed in this paper are not necessarily those of the United States Government or the sponsoring agency. 


\title{
Integrated Efficiency Test for Pyrochemical Fuel Cycles
}

\author{
S. X. Li, D. Vaden, B. R. Westphal, G. L. Fredrickson, R. W. Benedict, and T. A. Johnson \\ Materials and Fuels Complex, Idaho National Laboratory, Idaho Falls, ID, 83415 shelly.li@inl.gov
}

\begin{abstract}
An integrated efficiency test was conducted with sodium bonded, spent EBR-II drive fuel elements. The major equipment involved in the test were the element chopper, Mk-IV electrorefiner, cathode processor, and casting furnace. Four electrorefining batches (containing $54.4 \mathrm{~kg}$ heavy metal) were processed under the fixed operating parameters that have been developed for this equipment based on over a decade's worth of processing experience. A mass balance across this equipment was performed. Actinide dissolution and recovery efficiencies were established based on the mass balance and chemical analytical results of various samples taken from process streams during the integrated efficiency test.
\end{abstract}

\section{INTRODUCTION}

Pyrochemical processing plays an important role in the development of next generation nuclear reactors and closed nuclear fuel cycle technologies. The Idaho National Laboratory (INL) has implemented a pyrochemical process for the treatment of sodium-bonded spent fuel from the Experimental Breeder Reactor-II (EBR-II). A successful demonstration of the treatment technology at an engineering scale was performed from 1996 to 1999 for the Department of Energy (DOE) [1]. Processing of the spent fuel and associated research and development activities are currently performed under DOE's Global Nuclear Energy Partnership (GNEP) program.

An integrated efficiency test was performed with four batches (nominally $50 \mathrm{~kg}$ heavy metal) of spent EBR-II driver fuel. The equipment involved in the test were the element chopper (EC), Mk-IV electrorefiner (ER), cathode processor (CP), and casting furnace (CP). The primary goal of the integrated efficiency test was to demonstrate the actinide dissolution and recovery efficiencies typical of the fixed operating parameters that have been developed for this equipment based on over a decade's worth of processing experience. This paper summarizes the observations and results obtained from the test. The data collected will be used to further optimize the performance of the existing system. The findings are also of importance for scaling-up the pyrochemical process to recover and recycle actinide values from EBR-II and other sources of spent nuclear fuel.

\section{PROCESS DESCRIPTIONS AND EXPERIMENT}

The EC, ER, CP, and CF are located in an argonshielded hot cell in the Fuel Conditioning Facility (FCF) located at INL's Materials and Fuels Complex. Figure 1 shows the process flowsheet that served as the basis for the mass balance of the integrated efficiency test.

The EBR-II driver fuel is a highly enriched metallic uranium-zirconium alloy clad in stainless steel. Sodium metal, which served as a thermal bond in the reactor, is present in each fuel element. The irradiated driver fuel elements were chopped into $0.64-\mathrm{cm}$ long segments at the $\mathrm{EC}$ in preparation for electrorefining. This is the most suitable segment length based on experience with electrorefining of the spent fuel [2].

The chopped fuel segments were placed in a perforated stainless steel basket, which served as the anode during electrorefining. Each anode basket contained segments from three spent driver fuel assemblies (nominally $12.5 \mathrm{~kg}$ heavy metal). The ER is a batch unit operation with one loaded anode basket per batch. Four batches of the spent fuel were electrorefined during the integrated efficiency test.

The inside diameter and height of the ER vessel are $1.0 \mathrm{~m}$ and $1.0 \mathrm{~m}$, respectively. The vessel contains an approximately $10-\mathrm{cm}$ thick bottom layer of molten cadmium (the "Cd pool") and a 32-cm thick top layer of molten electrolyte (or "salt") that is composed of the $\mathrm{LiCl}-\mathrm{KCl}$ eutectic with 5.5 to $6.0 \mathrm{wt} \%$ of uranium as $\mathrm{UCl}_{3}$. The cathode is a mild steel cylindrical mandrel, $6.67 \mathrm{~cm}$ in diameter, with an electrochemically active length of approximately $23 \mathrm{~cm}$.

When the loaded anode basket is submerged into the molten salt, the bond sodium and active metal fission products undergo redox reactions with the $\mathrm{UCl}_{3}$. Sodium chloride and fission product chlorides are formed, while some of the $\mathrm{U}^{3+}$ is reduced to metallic form. With the application of a potential across the electrodes, uranium in the fuel segment is electrochemically transported from the anode to the cathode. An oxidant, $\mathrm{CdCl}_{2}$, is periodically added into the ER during the course of electrorefining processes to maintain the $\mathrm{UCl}_{3}$ concentration in the electrolyte. The $\mathrm{CdCl}_{2}$ oxidizes any metallic uranium in 


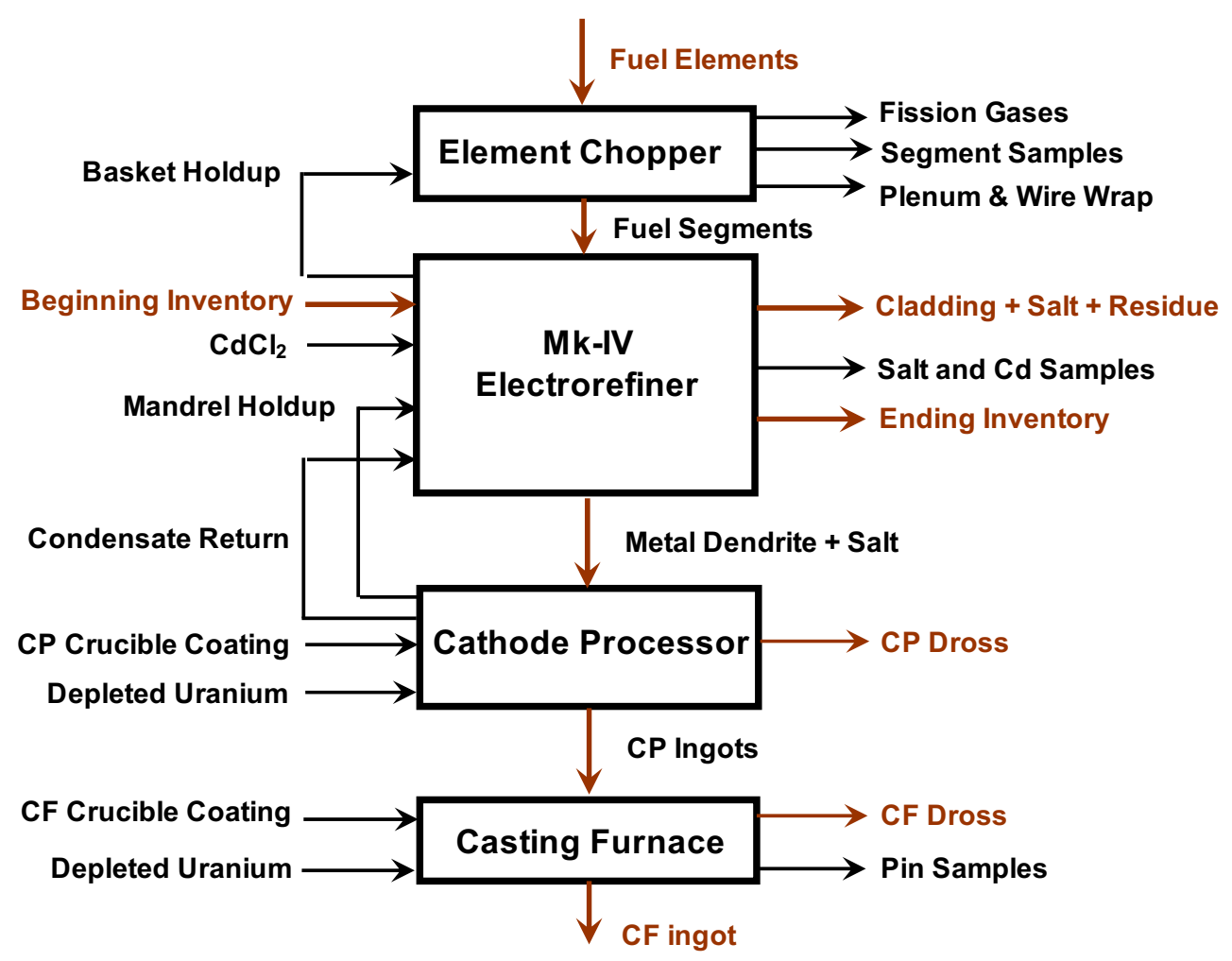

Fig. 1 Integrated efficiency test flowsheet.

contact with the molten salt, which is often present in the electrorefiner in more than one location, e.g., as uraniumzirconium alloy in the fuel in the anode basket, as uranium dissolved in the $\mathrm{Cd}$ pool, and as uranium deposits on the cathode mandrel. The overall process has been described in more detail elsewhere [1,2]. Table 1 gives the fixed ER operating parameters used for the test.

Table 1. ER Fixed Operating Conditions for Integrated Efficiency Test

\begin{tabular}{l|l}
\hline Parameter & Fixed Conditions \\
\hline Feed Material & EBR-II Driver Fuel \\
\hline Fuel Segment Length & $0.64 \mathrm{~cm}$ \\
\hline ER Operating Temperature & $500^{\circ} \mathrm{C}$ \\
\hline Anode and Cathode Rotation & 50 and $5 \mathrm{rpm}$ \\
\hline ER Operating Mode & Constant Current \\
\hline Cell Cut-off Voltage & $1.4 \mathrm{~V}$ \\
\hline$*$ Anode Cut-off voltage & $0.7 \mathrm{~V}$ \\
\hline$*$ Cathode Cut-off Voltage & $-1.0 \mathrm{~V}$ \\
\hline U3+ Concentration in Salt & $5.50 \sim 6.00 \mathrm{wt} \%$ \\
\hline
\end{tabular}

* The voltage difference between the electrode and ER vessel.
Typically, three to four cathodes were harvested per loaded anode basket (i.e., per batch). The end-point for each batch was determined by weighing the anode basket to assure that the net residue mass was less than $3.0 \mathrm{~kg}$. The residue mass includes any undissolved fuel constituents and adhering salt, and is generally referred to as "cladding hulls". Cladding hull samples were taken from the anode basket after each of the four electrorefining batches for chemical analysis to evaluate dissolution efficiency.

The electrorefining products (i.e., the harvested cathode deposits consisting of metal dendrites and adhering salt) were processed in CP to separate the salt from metal. The $\mathrm{CP}$ uses high-temperature vacuum distillation to remove adhering salt and consolidate metal. The salt condensate was returned back to ER and metal ingots were transferred downstream to the $\mathrm{CF}$, where pin samples were taken to determine the metal product composition. Depleted uranium was added during the $\mathrm{CP}$ and $\mathrm{CF}$ operations to create low enriched uranium ingots.

\section{RESULTS AND DISCUSSION}

\section{A. Total Mass Balance}

Figure 1 shows the major "input" and "output" streams across the equipment for the integrated efficiency 
test. For ER operations, liquid level measurements were performed before and after the test to determine the salt and cadmium inventories via volume calibration equations [3]. Following the level measurements, salt and cadmium samples were taken to obtain analytical results to calculate corresponding component inventories. Condensate collected during the $\mathrm{CP}$ operations supporting the integrated efficiency test was returned to the ER prior to collecting the final salt and cadmium samples.

A mass balance around ER, CP, and CF was performed based on the flowsheet shown in Fig. 1. The total mass balance was $101.28 \%$ (i.e., the balance indicated slightly more output than input). This mass balance provided an indication that all the significant inventories and process streams were included in the mass balance. This also established a baseline for the dissolution and recovery efficiency analysis.

Figure 2 provides the masses of uranium, zirconium, technetium, cerium, and neodymium in the feedstock, ER inventories, anode residues, $\mathrm{CP}$ and $\mathrm{CF}$ dross, and final $\mathrm{CF}$ ingots. The integrated process efficiencies were calculated as follows.

\section{B. Dissolution Efficiency}

The compositions of cladding hulls in the anode baskets (with regards to the amounts and compositions of the stainless steel cladding, adhering salt, and undissolved fuel residual) from each ER batch were estimated by the net weight and analytical results of the cladding hulls. Four collections of cladding hull samples were independently analyzed from each anode basket. Each collection consisted of ten or eleven cladding hull pieces. Special sampling methods, analytical procedures, and data reduction methodology have been reported previously [4]. The dissolution efficiencies were calculated by the ratio of the element quantities left in the cladding hulls (recovered from the anode baskets) in relation to their quantities in the chopped segments (loaded into the anode baskets). It can be seen in Fig. 2 that the dissolution efficiency of $99.3 \%$ was achieved for uranium $(50.399 \mathrm{~kg}$ of uranium entered the process in the feed stream and $0.336 \mathrm{~kg}$ of uranium left the process in the anode residue stream). The dissolution efficiencies for zirconium, technetium, cerium, and neodymium were 85.5, 15.9, 96.9, and $96.1 \%$, respectively.

\section{C. Recovery Efficiency}

The electrorefining process involved chemical reactions and electrochemical transports. The chemical reactions included the exchange of $\mathrm{U}^{3+}$ with sodium, transuranics, and active metal fission products in the spent fuel. These exchange reactions reduced the $\mathrm{U}^{3+}$ concentration in the electrolyte. As a routine ER operation step, $\mathrm{CdCl}_{2}$ was added into the electrolyte to

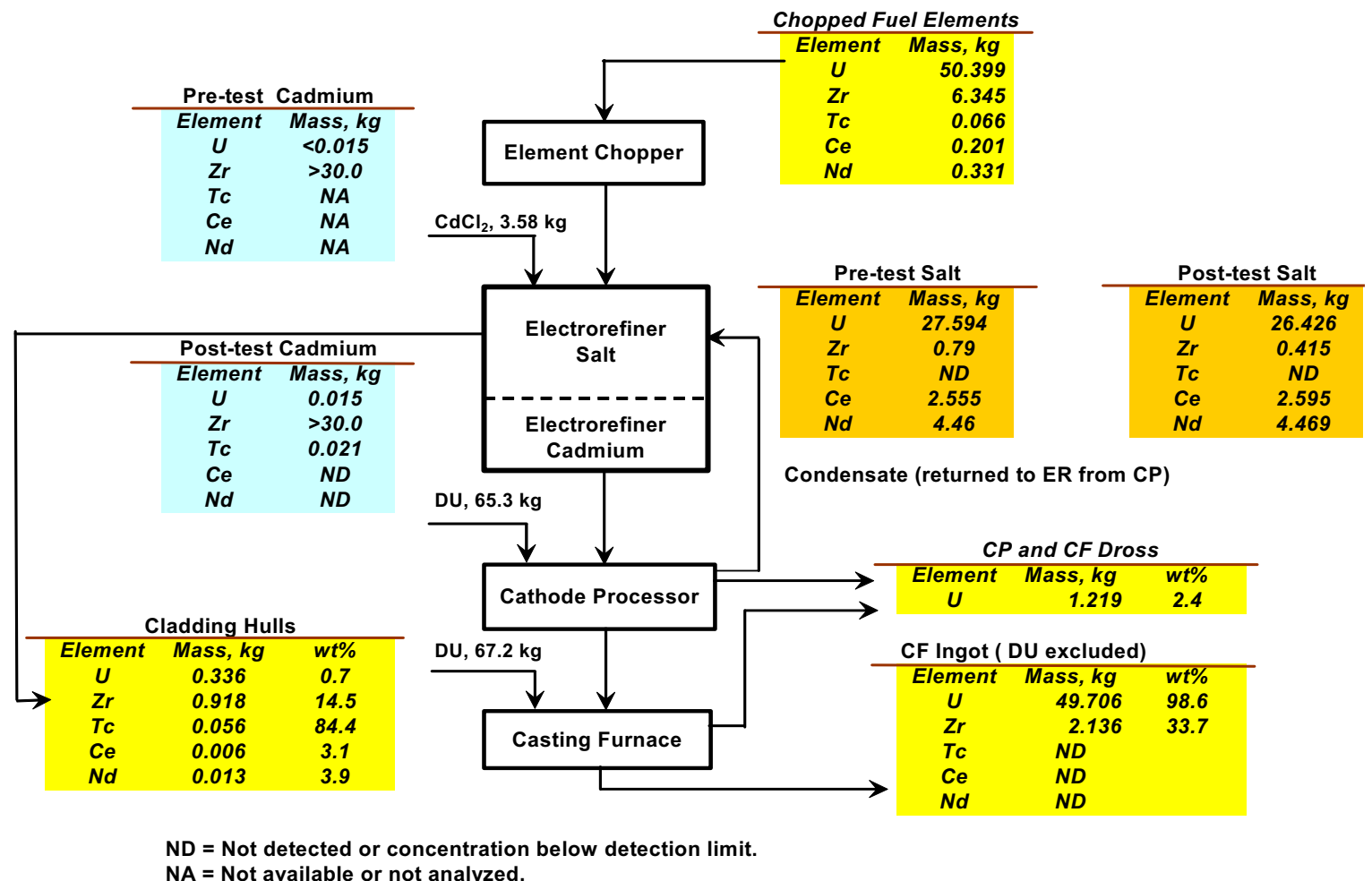

Fig. 2. Masses of key elements during the integrated efficiency test. 
maintain the $\mathrm{U}^{3+}$ concentration. A near constant $\mathrm{U}^{3+}$ concentration during the course of electrorefining operations reflects the effectiveness of this process control strategy. In contrast, improper chemical additions will result in an increasing or decreasing uranium inventory in the electrolyte. However, the inventory change will not have a noteworthy impact on electrochemical transport efficiency unless the U3+ concentration was significantly reduced, which is unlikely under the ER's normal operation conditions. For the integrated efficiency test, four batches of the spent fuel were electrorefined. Over the course of this test, the uranium inventory in the electrolyte varied from 27.6 to $26.4 \mathrm{~kg}$, or in a range of 5.94 to $5.57 \mathrm{wt} \%$ from beginning to end, respectively.

Uranium can dissolve in the $\mathrm{Cd}$ pool beneath the molten salt. Any uranium accumulated in the $\mathrm{Cd}$ pool can be electrochemically recovered [2]. However, there was little uranium in the $\mathrm{Cd}$ pool during the test. Therefore, for the integrated efficiency test, the recovery efficiency of an element was defined as the ratio of the quantity of its mass in the $\mathrm{CF}$ ingot in relation to its mass in the chopped segments. The inventory variations in the $\mathrm{Cd}$ pool (because they were negligible) were not included in the calculation. The recovery efficiencies of uranium, zirconium, technetium, cerium, and neodymium are easily calculated from the data presented in Fig. 2. The uranium recovery efficiency was $98.6 \%(50.399 \mathrm{~kg}$ of uranium entered the process in the feed stream and $49.706 \mathrm{~kg}$ of uranium left the process in the CF ingot stream). The zirconium recovery efficiency will be discussed in a later section of this report.

It was found through the integrated efficiency test that $2.4 \mathrm{wt} \%$ of the uranium was lost to the $\mathrm{CP}$ and $\mathrm{CF}$ dross streams. The CP dross is the primary contributor to this loss and is based on the reaction of molten uranium with the zirconia coating according to equation (1):

$\mathrm{ZrO}_{2}+\mathrm{U} \rightarrow \mathrm{UO}_{2}+\mathrm{Zr}$

A zirconia coating is used on the graphite process crucibles in the $\mathrm{CP}$ to minimize the reaction of uranium with the graphite and to ease the ingot release. The characteristics of the dross formation and $\mathrm{CP}$ operating experience have been documented elsewhere [5]. The development of alternatives for zirconia coating is currently being pursued to eliminate the loss of uranium to the dross streams.

\section{D. Zirconium Distributions in Process Streams}

Zirconium, which is a major component and accounts for $10 \mathrm{wt} \%$ or $26 \mathrm{vol} \%$ of the spent fuel (U-10Zr alloy), has complex behaviors in the electrorefining system [5].
The data in Fig. 2 indicate that greater than $85 \mathrm{wt} \%$ of the zirconium in the feed was electrochemically dissolved along with the uranium. One third of the zirconium was electrochemically deposited to the cathode, and consolidated into the final $\mathrm{CF}$ ingots. The balance of the zirconium should accumulate in the $\mathrm{Cd}$ pool. The ER contained approximately $700 \mathrm{~kg}$ of cadmium. The solubility of zirconium in cadmium at $500^{\circ} \mathrm{C}$ is $0.21 \mathrm{wt} \%$. It is estimated that more than $30 \mathrm{~kg}$ of zirconium have been accumulated in the ER since 1996. Unfortunately, an accurate zirconium inventory change during the integrated efficiency test could not be measured because the Cd pool was saturated with zirconium prior to the test.

Figure 3 shows pictures of the cathodes produced from the second ER batch of the integrated efficiency test. Cathode No. 3 in this figure clearly has a different morphology than that of the other two. The morphologies of the first and second cathodes are typical of highuranium deposits, and the morphology of the third cathode is typical of a high-zirconium deposit [6]. The morphologies of the cathodes produced during the other three batches were similar to those shown in Fig. 3. It seems that the zirconium was electrochemically transferred at a later stage of the electrorefining process.

To gain a better understanding of the materials transferred during different stages of electrorefining, the first cathode produced in each ER batch were combined in the $\mathrm{CP}$ and $\mathrm{CF}$ runs. The second and third cathodes from each ER batch were also segregated in this manner for processing in the $\mathrm{CP}$ and $\mathrm{CF}$. Table 2 gives the uranium and zirconium contents in the cathode product produced during the different electrorefining stages. The data in Table 2 confirm that most of the zirconium was transferred in the latter stages of electrorefining due to the depletion of uranium from the anode basket.

Table 2. Zr Collected at Different Stage of Electrorefining

\begin{tabular}{l|c|c}
\hline Cathode & Zr wt\% & U wt\% \\
\hline No. 1 & 0.58 & 99.35 \\
\hline No. 2 & 0.88 & 99.06 \\
\hline Nos. 3 and 4 & 8.89 & 91.06 \\
\hline
\end{tabular}

Results from the CP runs have shown that the salt fraction in the first, second, and third cathode products were $24.1,28.7$, and $43.8 \mathrm{wt} \%$, respectively. It was expected that zirconium would be electrochemically transferred in the latter stages of electrorefining, due to the depletion of uranium from the anode basket. It appeared that the increase of the zirconium concentration in the cathode deposit altered the cathode morphology, and resulted in more salt cohering to it. 


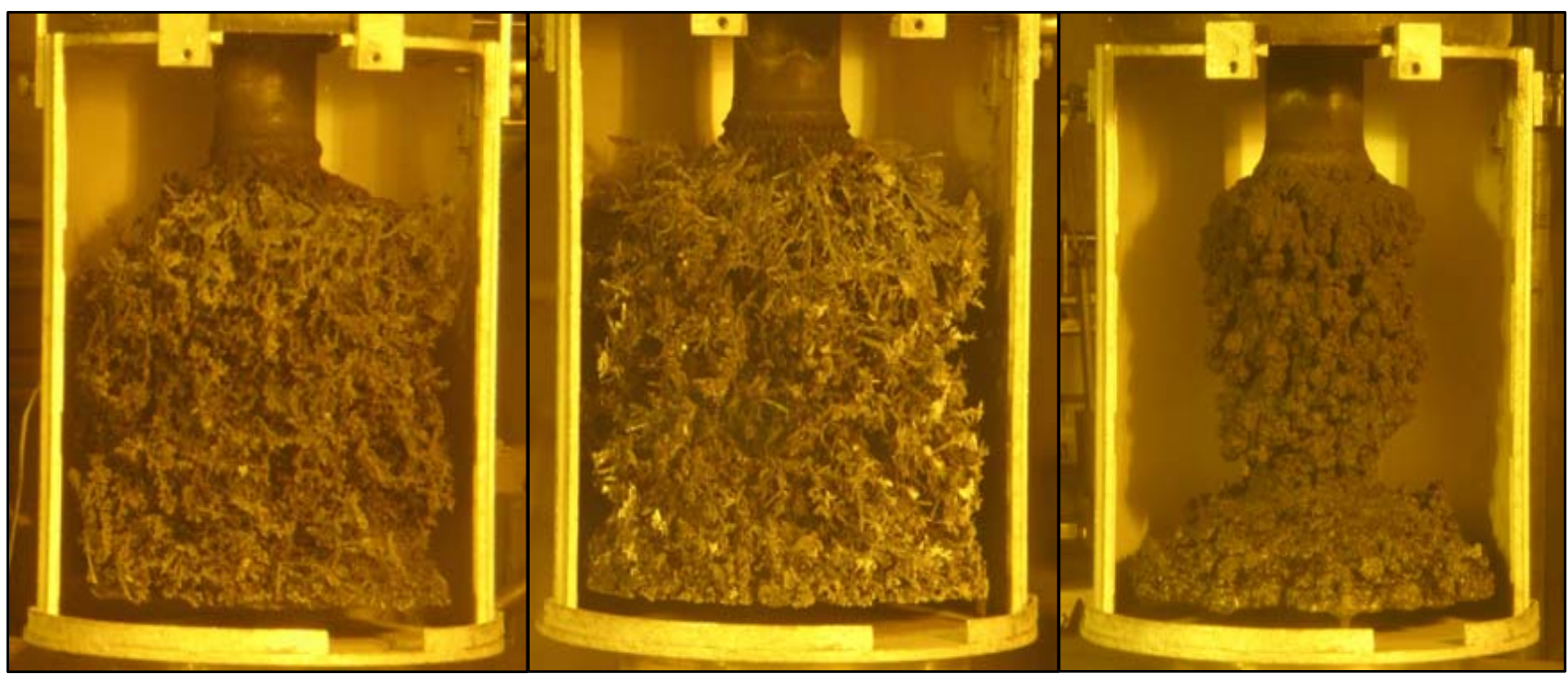

Fig. 3. Three cathodes produced during the second ER batch of the integrated efficiency test.

\section{SUMMARY}

An integrated efficiency test was successfully performed with sodium-bonded spent EBR-II driver fuel in FCF hot cell. Fifty-four kg heavy metal was processed through EC, ER, CP, and CF under fixed operating conditions. This was the first time that an integrated test was conducted in such a scale with spent fuel. The total mass balance for the test was $101.28 \%$ (slightly more output than input). The test results indicate that $99.3 \mathrm{wt} \%$ of uranium in the feed was electrochemically dissolved and $98.4 \mathrm{wt} \%$ of the uranium was collected in the CF ingot. The complexity of zirconium behavior during electrorefining was confirmed by the test results. Greater than $85 \mathrm{wt} \%$ of the zirconium was electrochemically dissolved during the later stage of electrorefining process. However, only $33.7 \mathrm{wt} \%$ of the zirconium was collected in the CF ingot. The balance of the zirconium is believed to reside in the $\mathrm{Cd}$ pool. The test also identified that the CP and CF dross streams account for approximately 2.4 $\mathrm{wt} \%$ of the uranium relative to the feed. Research and development activities are underway to eliminate (or minimize) the loss of uranium to the dross streams. Also, work is in progress on investigating hold-up in each piece of equipment to determine both overall and individual element change during operation.

\section{ACKNOWLEDGMENTS}

The authors acknowledge the work performed by the staff of the Analytical Laboratory at INL's Materials and Fuels Complex and their important contributions to analytical procedures and sample analyses. This work was supported by the U.S. Department of Energy, Office of Nuclear Energy, Science, and Technology under DOENE Idaho Operations Office Contract DE-AC0705ID14517. The submitted manuscript was authored by a contractor of the U.S. Government. Accordingly, the U.S. Government retains a nonexclusive, royalty-free license to publish or reproduce the published form of this contribution, or allow others to do so, for U.S. Government purposes.

This information was prepared as an account of work sponsored by an agency of the U.S. Government. Neither the U.S. Government nor any agency thereof, nor any of their employees, makes any warranty, express or implied, or assumes any legal liability or responsibility for the accuracy, completeness, or usefulness of any information, apparatus, product, or process disclosed, or represents that its use would not infringe privately owned rights. References herein to any specific commercial product, process, or service by trade name, trademark, manufacturer, or otherwise, does not necessarily constitute or imply its endorsement, recommendation, or favoring by the U.S. Government or any agency thereof. The views and opinions of authors expressed herein do not necessarily state or reflect those of the U.S. Government or any agency thereof.

\section{REFERENCES}

1. "Electrometallurgical Techniques for DOE Spent Fuel Treatment: Final Report," National Research Council, National Academy Press, Washington, DC (2000). 
2. S. X. Li, T. A. Johnson, B. R. Westphal, K. M. Goff, and R. W. Benedict, "Electrorefining Experience For Pyrochemical Reprocessing of Spent EBR-II Fuel," Proceedings of GLOBAL 2005, Tsukuba, Japan, October 2005.

3. S. X. Li and M. F. Simpson, "Anodic Process of Electrorefining Spent Driver Fuel in Molten LiClKCl-UCl3/Cd System," Journal of Mineral and Metallurgical Processing, Vol. 22, No. 4, 2005

4. S. X. Li, R. D. Mariani , T. J. Battisti, and R. S. Herbst, "Initial Results for Electrochemical Dissolution of Spent EBR-II Fuel," Proceedings of the DOE Spent Nuclear Fuel and Fissile Materials Management, American Nuclear Society, Charleston, SC, September 8-11, 1998.

5. B. R. Westphal, A. R. Brunsvold, P. D. Roach, and D. V. Laug, "Initial Cathode Processing Experience and Results," Proceedings of the DOE Spent Nuclear Fuel and Fissile Materials Management, American Nuclear Society, Reno, NV June 16-20, 1996.

6. S. X. Li, T. A. Johnson, B. R. Westphal, K. M. Goff, and R. W. Benedict, " Electrochemical Co-Collection of Uranium and Zirconium in Mk-IV Electrorefiner for Treating Spent EBR-II Driver Fuel," Trans. American Nucl. Soc., ANS, 93, pp. 741, 2005. 